\title{
The Implementation of SAVI (Somatic, Auditory, Visual and Intellectual) to Increase the Students' English Structure at English Education Department
}

\author{
Samsi Rijal 1, Nurdiana Arifah2 \\ Universitas Islam Madura / FKIP1 ${ }^{1}$, IAIN Madura / Fakultas Tarbiyah ${ }^{2}$ \\ samsirijal1983@gmail.com; nurdianaarifah84@gmail.com²
}

\begin{abstract}
This research began from the students' problems in understanding the English structure at the first semester of English Education Department, Teacher Training and Education Faculty, Madura Islamic University (UIM) Pamekasan. From the data, it showed that most of students did not achieve the target score 75 (B), it was only $43.75 \%$ students. These problems occurred because 1) they used to memorize the pattern of English structure, 2) they seldom practice it in spokenor written, 3) they felt afraid of making mistakes. Concerning with these, the researcher tried to solve by implementing an appropriate strategy, it is SAVI (Somatic, Auditory, Visual and Intellectual) which was introduced by Dave Meire. The research design is Classroom Action Research (CAR). It was done in two cycles with four steps; planning, acting, observing and reflecting. After conducting the research, there were significant improvements of students' score. From the data, in the preliminary study, there were only $43.75 \%$ who achieved the target score. After implementing SAVI in the cycle I, there were improvement of students score, it was $62.5 \%$ students who achieved the target score. In cycle II, there were $87.5 \%$ students. From the data above, it could be concluded that implementing SAVI is success because it achieved the target score, it is more than $85 \%$ students got 75 (B).
\end{abstract}

Keyword : SAVI (somatic, auditory, visual and intellectual), English structure.

\section{INTRODUCTION}

Language is still one of tools which most of people used in communication, by the language they can deliver and receive the information easily. One of the languages that mostly people used in the world is English language, it is one of international languages. For its important, many countries made this language as the formal language such as Malaysia, Singapore and India. In Indonesia, English language is still foreign language for most students although it was learned from a basic formal institution. According to (SHOLIHIN, 2015) this foreign language(English) is being taught from junior high school up to senior high school as a compulsory subject. In fact, many students of university still felt difficult in learning English language. 
Talking about learning English, there are four skills that must be mastered by students. They are listening, speaking, reading and writing. Concerning to these skills, some language components such as structure, vocabulary and others are needed to develop those skills. In the level of university especially at English Education Department Madura Islamic University (UIM) Pamekasan, structure is one of the subjects which the students learn from the first semester until the forth semester. Based on the observation, the researcher found many problems that faced by students in the process of teaching and learning. The students felt difficult in understanding the English structure because they learned by memorizing the pattern, they seldom practice it in the class.

Related to the problems above, the lecturer must solve problems by choosing the best strategy in teaching and learning English structure. One of strategies which can be used is SAVI (Somatic, Auditory, Visual And Intellectual). According to Dave Meire in (Rusman, 2012)book (2012:373) stated that SAVI is one strategy in teaching and learning process which involve the five senses. Furthermore(Dave, 2002) describe that the characteristics of it, namely; the first is Somatic, in this step learners are invited to learn by doing something and moving. In addition(Iskandar et al., 2016) stated that activity-based learning in general is much more effective than those based presentations the materials. The second is Auditory, by using this strategy, learners will learn with speaking and listening. According to (Iskandar et al., 2016) stated that teachers should encourage students to talk about what they are learning. The third is Visual, learners will learn by investigating and drawing what they will. (Huda, 2013) stated that in learning by hearing, the lecturer or teachers can ask students to make something such as summary, picture and diagram what they have learned in the class. The last is Intellectual; this one will train the learners in solving the problem. In addition,(Iskandar et al., 2016)stated that SAVI highlight how students create their own activity. This will affect the students' way of thinking becomes more open and try to dig ability in acquiring new knowledge.

\section{METHOD}

This research design of this research is CAR (classroom action research) which has objective to solve the students' problem in learning English structure at first semester of English Education Department Madura Islamic University and it also improve the quality of teacher or lecturer in the process of teaching and learning. It is relevant with the statement of (Winarso, 2008)that the objective of CAR is to increase the lecturers or teachers quality and give them more understanding in how to get the goal of teaching and learning process. Furthermore he stated that this research (CAR) offer the alternative solution to make the process run better and better.

According to(Kemmis, S. \& R. Mc Taggart, 1981)There are four steps in conducting the classroom action research after doing preliminary study. The first is planning, the second is acting, the third is observing and the fourth is reflecting.

\section{ENGLISH EDUCATION}

Journal of English Teaching and Research 
Here are the steps in conducting CAR (classroom action research);

Figure.1 Action Research Cycle

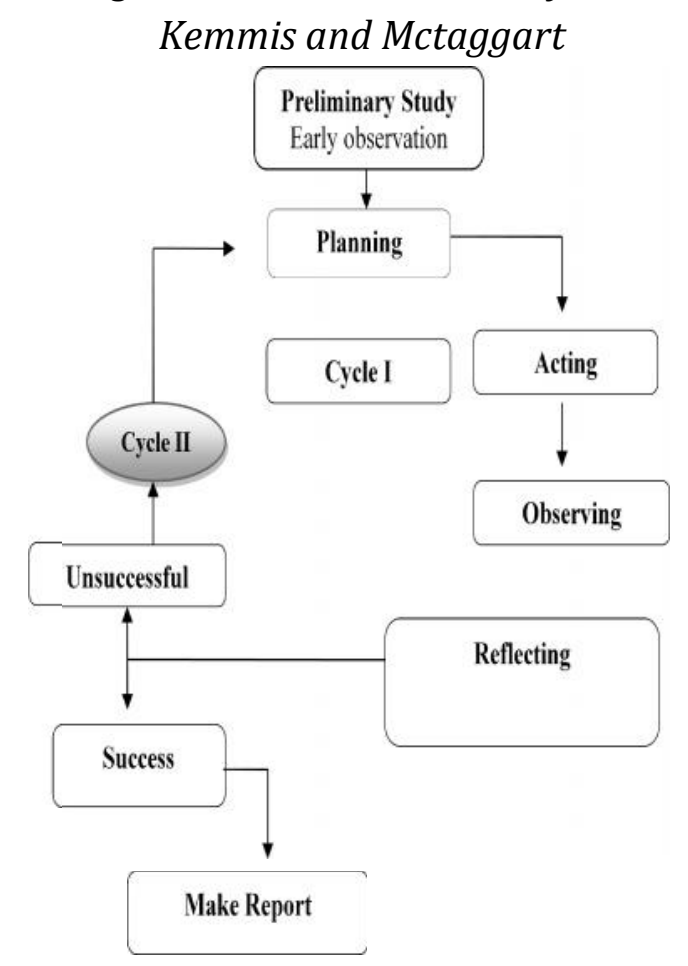

The subject of this research is the students of the first semester of English Education Department, Madura Islamic University (UIM) Pamekasan, In collecting the data, the researcher used observation and test. Observation was used to know the condition of students in joining the process of teaching and learning in the class, while the test was used to know the improvement of students' score of English structure. The last is in analyzing the data, the researcher used the criteria of success to measure the research. In this research, the researcher made the target of this research, it is $85 \%$ of students got the minimum score, it is 75 (B).

\section{THE RESULTS}

The researcher took the data three times. They are preliminary study, cycle I and cycle II.

\section{Preliminary study}

In this section, the researcher did the observation related to the students' understanding about their English structure, especially students at the first semester of English Education, Teacher Training and Education Faculty (FKIP) Madura Islamic University (UIM) Pamekasan.

Based the observation, the researcher found many problems that made them did not achieve the target minimum of English structure, it is 75 (B). The data showed that the students who got the target score is $43.75 \%$ and only $56.25 \%$ students did not. From that result, the researcher planned to choose the best strategy to solve their problem, it is SAVI (Somatic, Auditory, Visual and Intellectual). 


\section{The first cycle}

This cycle I was done on $10^{\text {th }}$ of November 2019.

\section{Planning}

The researcher planned the teaching and learning process based on the students' problems in understanding the English structure. In this section the researchers prepared the material that suitable to the topic (present progressive). The second, the researcher choose the strategy in teaching and learning process, it is SAVI (Somatic, Auditory, Visual and Intellectual) which is introduced by Dave Meire.

\section{Acting}

In the process of acting, there were three steps which the researcher did. They are Pre-activity, Main Activity and Closing Activity.

The first is Pre-activity. In this step, the researcher stimulated the students to the new material by asking some questions related to the topic that will be discussed.

The second is main activity. It is theprocess of teaching and learning English Structure through SAVI (Somatic, Auditory, Visual and Intellectual). The first is implementing SOMATIC, in this step, the researcher explained something related to the topic (present progressive) while students did or acted something. For example, when the researcher said "I am standing", all the students in the class must act or do "STANDING". The second example, the researcher said "I am reading a book", all students acted reading a book. These activities are called learning by doing.The second is using AUDITORY strategy. In this step, the researcher divided some students into some groups, each groups consist two students and have different jobs. The first student says something related to the topic (present progressive) and the other do the action what his or her friend says. Such as when the first student said "I am opening the door", his partner must go to the door and open it. The second example when his friend said "I am running", he acts running.The third is VISUAL activity. In this step, the researcher asked one of students to come in front of the class and act something while the others lookat the action and take note or write what he is acting using present progressive. The last is INTELLECTUAL activity. In this activity, the researcher trained the students to solve the problems by giving students some questions related to the topic that they have learned before. In this activity they learned to solve or answer the question correctly.

The third is closing activity. In this activity, the researcher reviews the materials by asking some questions to measure their understanding.

\section{Observing}

After conducting the research, the researcher saw the students are interested in joining the process of teaching and learning of English structure. It was showed by the score of students, there was improvement from the preliminary study. In this cycle, the students who got target score increased become $62.5 \%$ while they who did not get the target were $37.5 \%$ students.

\section{ENGLISH EDUCATION}

Journal of English Teaching and Research 


\section{Reflecting}

Based on the data above, it could be concluded that the implementation of SAVI (Somatic, Auditory, Visual and Intellectual) in the cycle I was success because there was improvement score who got the target score, it is $62.6 \%$. Based on the criteria of success, this score did not achieve the target of the research because the target was $85 \%$ of students must pass the score 75 (B). From this result, the researcher determined to continue this research to the second cycle II.

\section{The second cycle}

This cycle was done on $17^{\text {th }}$ of November 2019.

\section{Planning}

Based on the data in cycle I, the data showed that the result did not achieve the target even thought there were some improvement of students' understanding. In this cycle II, the researcher still used the same strategy, it is SAVI (Somatic, Auditory, Visual and Intellectual) with more practices about present progressive.

\section{Acting}

There are no different strategies in cycle II, the researcher still uses four activities; SOMATIC (learning by doing), AUDITORY (learning by hearing), VISUAL (learning by seeing/investigating/drawing) and INTELLECTUAL (learning by solving a problem) with more opportunities to the students to practice more.

\section{Observing}

By giving students more practices in using present progressive through SAVI strategy, they felt more enjoyable and interested in learning English structure and it made them easier to understand the topic because they were more active in the class, the lecturer only as facilitator in the class. It was also supported by the improvement of the students' score who got the target score, it is $87.5 \%$.

\section{Reflecting}

After conducting some steps in this research, here are the score of students from preliminary until cycle II:

\begin{tabular}{|l|l|c|c|c|}
\hline No & Name & $\begin{array}{c}\text { Preliminary } \\
\text { Score }\end{array}$ & $\begin{array}{c}\text { Cycle I } \\
\text { score }\end{array}$ & $\begin{array}{c}\text { Cycle II } \\
\text { score }\end{array}$ \\
\hline 1 & RL & 80 & 82 & 84 \\
\hline 2 & HQ & 78 & 80 & 84 \\
\hline 3 & AQ & 86 & 86 & 86 \\
\hline 4 & SA & 70 & 73 & 76 \\
\hline 5 & HF & 88 & 90 & 90 \\
\hline 6 & W & 69 & 70 & 75 \\
\hline 7 & IN & 72 & 75 & 77 \\
\hline 8 & M & 65 & 72 & 75 \\
\hline 9 & MF & 70 & 75 & 78 \\
\hline 10 & MH & 72 & 78 & 80 \\
\hline
\end{tabular}




\begin{tabular}{|l|l|c|c|c|}
\hline 11 & MS & 87 & 87 & 90 \\
\hline 12 & S & 71 & 74 & 76 \\
\hline 13 & S & 68 & 70 & 72 \\
\hline 14 & NH & 92 & 92 & 94 \\
\hline 15 & LR & 90 & 90 & 93 \\
\hline 16 & P & 65 & 69 & 70 \\
\hline & $\begin{array}{l}\text { The } \\
\text { average }\end{array}$ & $43.75 \%$ & $62.5 \%$ & $87.5 \%$ \\
\hline
\end{tabular}

Figure .2 Students score in preliminary study, cycle I and cycle II

\section{DISCUSSION}

After looking at the result of implementing SAVI (Somatic, Auditory, Visual and Intellectual) in the teaching and learning process of English structure from preliminary study until the second cycle, there were significant improvement score of students. In preliminary study, the average students who achieved the target score, it was only $43.75 \%$. In the first cycle, there was improvement became $62.5 \%$ and in the second cycle was $87.5 \%$. From these data, using SAVI is very effective to increase students' understanding of structure. It is also supported by the other research that was conducted by (Iskandar et al., 2016). They found that SAVI increases the critical thinking skills of students and it also made social problems in the local environment tend to be more positive in the class. In addition , the using of SAVI also can be used to improve the other language component such vocabulary that was done by (Sholihin, 2015). There was a significant progress of using SAVI, it showed by data in the pre-test and post-test of his research. From those the data above, it can be said that the use of SAVI (Somatic, Auditory, Visual and Intellectual) in increasing students' structure understanding is very effective.

\section{CONCLUSION}

Based on the previous discussion, the researcher can draw the conclusion: the first, the used of SAVI (Somatic, Auditory, Visual and Intellectual) in teaching English structure is success because it achieved the target of this research, there was more that $85 \%$ students who got the minimum score, it was $87.5 \%$ students. It also made students interested in learning English, it is in line with the result of (Iskandar et al., 2016) research that implementing SAVI make students happy and also easier in understanding the material. It was supported also by the research of (Sholihin, 2015), he stated that the implementation of SAVI is effective and improve the students' ability. The second, the students were more active in the class because it changed from teacher/lecturer center learning (TCL)to the students center learning (SCL). The third, the students had more opportunities to do exercise the class with their partner.

\section{REFERENCES}

Dave, M. (2002). The Accelerated Learning: A Creative Guide to Designing and Delivering Faster, More Effective Training Program. New York: Mc graw-Hill.

\section{ENGLISH EDUCATION}

Journal of English Teaching and Research 
Huda, M. (2013). Model-Model Pengajaran dan Pembelajaran: Isu-Isu Metodis dan Pragmatis. Yogyakarta:Pustaka Belajar.

Iskandar, D., Hamdani, A. R., \& Suhartini, T. (2016). Implementation of Model SAVI (Somatic, Audiotory, Visualization, Intellectual) to Increase Critical Thinking Ability in Class IVof Social Science Learning on Social Issues in the Local Environment. JETL (Journal of Education, Teaching and Learning), 1(1), 45. https://doi.org/10.26737/JETL.V1i1.35

Kemmis, S., \& R. Mc Taggart. (1981). The Action Research Planner. Victoria, Australia: Deakin University Press.

Rusman. (2012). Model-Model Pembelajaran: Menegembangkan Profesionalisme Guru. 2nd Edition. PT Rajagrafindo Persada. Jakarta.

Sholihin. (2015). The Using of SAVI (Somatic, Auditory, Visual and Intellectual) Technique in Improving the Students' Vocabulary at the Seventh Grade of SMPN 01 Monta Bima. Ganeç Swara Vol. 9 No.2 September 2015.

Winarso, H. P. (2008). Penelitian Tindakan Kelas; Meningkatkan Professionalitas Guru Dan Dosen. Um Press. Malang. 